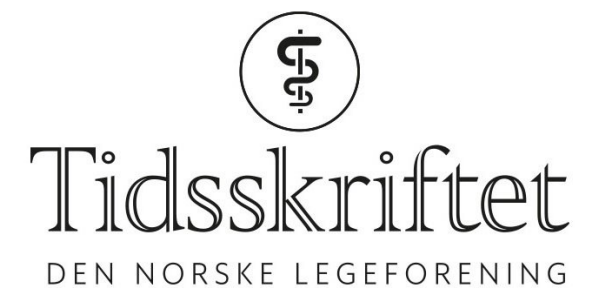

DEN NORSKE LEGEFORENING

\title{
Myokardfibrose ved medfødt hjertefeil
}

KOMMENTAR

\section{THOMAS MÖLLER}

E-post: thofmol@gmail.com

Thomas Möller er overlege og post-doc ved Barnekardiologisk avdeling, Barne- og ungdomsklinikken, Oslo universitetssykehus.

Ingen oppgitte interessekonflikter.

\section{CHARLOTTE DE LANGE}

Charlotte de Lange er overlege ved Barneradiologisk seksjon, Klinikk for Radiologi og Nukleærmedisin, Oslo universitetssykehus. Ingen oppgitte interessekonflikter.

Torvald Espeland og medarbeidere har skrevet en verdifull og interessant oversikt over myokardfibrose, men utelater å nevne et viktig kardiologisk fagfelt ved myokardfibrose, nemlig medfødte hjertefeil hos både barn og voksne (1). Medfødt hjertefeil forekommer hos ca. $1 \%$ av nyfødte. Langtidskomplikasjoner hos undergrupper med medfødte hjertefeil rammer derfor et betydelig antall pasienter, ofte i relativt ung alder.

I flere tiår har man hatt kunnskapen om fibroseutvikling som en bekymringsverdig langtidskomplikasjon tross kirurgisk reparasjon av hjertefeilen tidlig i livet (2). Fibroseutviklingen synes hos disse pasientene ikke kun å være knyttet til hjertefeilens alvorlighetsgrad eller cyanose, men også til genetiske faktorer. Myokardfibrose er en viktig medvirkende årsak til hjertesviktutvikling hos voksne med medfødte hjertefeil (3). Hos pasienter med enkel ventrikkel bidrar tidlig fibroseutvikling sannsynligvis til pumpesvikt i barnealder (4).

MR-undersøkelse med T1-mapping og beregning av ekstracellulært volum kan gi unik informasjon om myokard og grad av diffus fibrose, men er noe mer komplisert å bruke enn angitt i artikkelen. Metoden for T1-mapping er maskinspesifikk og ennå ikke helt standardisert for klinisk bruk. T1-relaksasjonstiden påvirkes av flere faktorer og forskjellige tekniske parametre, og ekstracellulært volum anses som en mer robust parameter. Derfor er det anbefalt å etablere lokale referanseverdier for å oppnå reproduserbare målinger av god kvalitet (5). Økt diffus myokardfibrose er påvist med T1-mapping ved ulike typer hjertefeil som Fallots tetrade, medfødt aortastenose, enkel ventrikkel og transposisjon av de store arterier (6).

Myokardfibrose er en viktig faktor for utvikling av nedsatt myokardfunksjon ved ervervede og medfødte hjertesykdommer. Korrekt anvendt kan MR-teknikker hjelpe med å forstå og kartlegge fibroseprosessen. 
1. Espeland T, Lunde IG, Amundsen BH et al. Myokardfibrose. Tidsskr Nor Legeforen 2018; 138: doi: 10.4045/tidsskr.17.1027. [PubMed][CrossRef]

2. Rathod RH, Powell AJ, Geva T. Myocardial Fibrosis in Congenital Heart Disease. Circ J 2016; 80: 1300 7. [PubMed][CrossRef]

3. Broberg CS, Burchill LJ. Myocardial factor revisited: The importance of myocardial fibrosis in adults with congenital heart disease. Int J Cardiol 2015; 189: 204 - 10. [PubMed][CrossRef]

4. Sugimoto M, Saiki H, Tamai A et al. Ventricular fibrogenesis activity assessed by serum levels of procollagen type III N-terminal amino peptide during the staged Fontan procedure. J Thorac Cardiovasc Surg 2016; 151: 1518 - 26. [PubMed][CrossRef]

5. Messroghli DR, Moon JC, Ferreira VM et al. Clinical recommendations for cardiovascular magnetic resonance mapping of $\mathrm{T}_{1}, \mathrm{~T}_{2}, \mathrm{~T}_{2}{ }^{*}$ and extracellular volume: A consensus statement by the Society for Cardiovascular Magnetic Resonance (SCMR) endorsed by the European Association for Cardiovascular Imaging (EACVI). J Cardiovasc Magn Reson 2017; 19: 75. [PubMed][CrossRef]

6. Riesenkampff E, Messroghli DR, Redington AN et al. Myocardial T1 mapping in pediatric and congenital heart disease. Circ Cardiovasc Imaging 2015; 8: eoo2504. [PubMed][CrossRef]

Publisert: 26. november 2018. Tidsskr Nor Legeforen. DOI: 10.4045/tidsskr.18.0864

(C) Tidsskrift for Den norske legeforening 2020. Lastet ned fra tidsskriftet.no 